\title{
Augmentation of the Natriuretic Activity of Exogenous and Endogenous Atriopeptin in Rats by Inhibition of Guanosine 3',5'-Cyclic Monophosphate Degradation
}

Martin R. Wilkins, Steven L. Settle, and Philip Needleman

Department of Pharmacology, Washington University School of Medicine, St. Louis, Missouri 63110

\begin{abstract}
To investigate the relationship between AP, cyclic GMP, and sodium excretion, we studied the effect of a cyclic GMP phosphodiesterase inhibitor $(M+B 22948)$ on the natriuretic response to (a) an infusion of AP (103-126) and (b) acute volume expansion in rats. The phosphodiesterase inhibitor markedly potentiated the effect of low-dose AP infusions on urinary sodium and cyclic GMP excretion without potentiating the fall in blood pressure. Acute volume expansion (1\% body wt) led to small but significant $(P<0.01)$ rises in plasma $A P$ and urinary cyclic GMP levels. Pretreatment with the phosphodiesterase inhibitor enhanced the natriuretic and cyclic GMP response to volume loading, an effect that was attenuated by administration of a monoclonal antibody directed against AP. These data indicate that cyclic GMP mediates the natriuretic activity of AP and AP and cyclic GMP play active roles in the natriuresis of acute volume expansion. Moreover, pharmacological manipulation of cyclic GMP levels may prove a useful therapeutic strategy for facilitating the natriuretic but not the hypotensive effects of AP. (J. Clin. Invest. 1990. 85:1274-1279.) atrial peptide • volume-expansion • phosphodiesterase
\end{abstract}

\section{Introduction}

Atriopeptin (AP, 99-126) ${ }^{1}$ is a naturally occurring 28 -amino acid peptide with natriuretic-diuretic and vasodilator properties (1). Synthesized and stored in cardiac atria, it is released into the circulation in response to atrial stretch (2). Circulating $\mathrm{AP}$ is thought to have a role in regulating intravascular volume. Consistent with this, plasma levels rise with intravascular volume expansion (3) and fall with volume depletion (4). Moreover, pretreatment of rats with monoclonal antibody raised against AP markedly attenuates the natriuretic response of these animals to acute volume expansion (5).

There is increasing evidence that cyclic GMP functions as an intracellular mediator of the biological activity of AP. The peptide increases cyclic GMP levels in a number of tissues, notably renal glomeruli and collecting ducts, vascular endo-

Address reprint requests to Dr. P. Needleman, Department of Pharmacology, Washington University School of Medicine, St. Louis, MO 63110 .

Received for publication 28 August 1989 and in revised form 28 November 1989.

1. Abbreviations used in this paper: $\mathrm{AP}$, atriopeptin; $\mathrm{AP}_{\mathrm{ir}}, \mathrm{AP}$ immunoreactivity; BNP, brain natriuretic peptide.

\footnotetext{
J. Clin. Invest.

(c) The American Society for Clinical Investigation, Inc.

0021-9738/90/04/1274/06 \$2.00

Volume 85, April 1990, 1274-1279
}

thelium and smooth muscle, and the adrenal gland (6-11). Early studies demonstrated that this was due to stimulation of particulate guanylate cyclase rather than inhibition of phosphodiesterase activity $(9,10)$. More recently, cloning and expression of the gene for particulate guanylate cyclase in COS-7 cells demonstrated that this enzyme behaves as a receptor for AP (12). However, while it is recognized that cyclic GMP may modulate vascular tone (13), the idea that it also regulates urinary sodium excretion has not been adequately resolved. Support for such a role comes from studies which show that cyclic GMP reproduces the effects of AP on glomerular filtration rate (6), sodium transport across renal inner medullary collecting ducts $(14,15)$ and renin secretion from juxtaglomerular cells (16). In addition, cyclic GMP phosphodiesterase inhibition has been reported to enhance AP-induced inhibition of sodium-dependent oxygen consumption by renal inner medullary collecting ducts (14). Nevertheless, while one study found a close relationship between AP-stimulated natriuresis and urinary cyclic GMP levels (17), two other studies have demonstrated a dissociation between urinary cyclic GMP and urinary sodium excretion $(18,19)$.

If cyclic GMP is an important mediator of the renal effects of AP, then it should be possible to potentiate the action of AP on sodium excretion by cotreatment with a cyclic GMP phosphodiesterase inhibitor. Accordingly, we have investigated in rats the effect of $M+B 22948$, a selective cyclic GMP phosphodiesterase inhibitor (20), on the natriuresis associated with $(a)$ exogenous AP infusion and $(b)$ acute intravascular volume expansion.

\section{Method}

$A P(103-126) / M+B 22948$ infusions. Polyethylene catheters (PE50) were inserted into the femoral vein, femoral artery, and bladder of male Sprague-Dawley rats (250-325 g) anesthetized with ether. The animals were then placed in individual restraining cages and allowed to regain consciousness. An infusion of 5\% dextrose, $0.225 \%$ sodium chloride $(0.07 \mathrm{ml} / \mathrm{kg}$ per $\mathrm{min})$ via the femoral vein, was commenced and continued for the remainder of the study period. Observations were begun $90 \mathrm{~min}$ after the start of the infusion. Urine was collected into preweighed tubes and blood pressure measured (via femoral artery by pressure transducer type 4-327-0010; Bell \& Howell Co., Pasadena, CA) every $15 \mathrm{~min}$ for the next $120 \mathrm{~min}$. All drugs were administered via the femoral vein in the dextrose-sodium chloride vehicle. Blood $(300 \mu \mathrm{l})$ was collected into $50 \mathrm{mM}$ EDTA $(1: 9, \mathrm{vol} / \mathrm{vol})$ before and after each infusion for measurement of plasma AP immunoreactivity.

In a preliminary study, rats received one of four doses of $M$ + B22948 $(0.03,0.1,0.34$, or $1.0 \mathrm{mg} / \mathrm{kg}$ per $\mathrm{min})$ by infusion for 45 min. $M+B 22948$ produced a dose-dependent rise in urinary cyclic GMP and sodium excretion and fall in blood pressure (Fig. 1). 0.03 $\mathrm{mg} / \mathrm{kg}$ per min was found to be the threshold dose for a consistent detectable rise in urinary cyclic GMP and sodium excretion, whereas a fall in blood pressure was first seen at $0.34 \mathrm{mg} / \mathrm{kg}$ per min. 0.03 and $0.34 \mathrm{mg} / \mathrm{kg}$ per $\mathrm{min}$ were selected for further investigation of the effects of this drug on AP activity. 


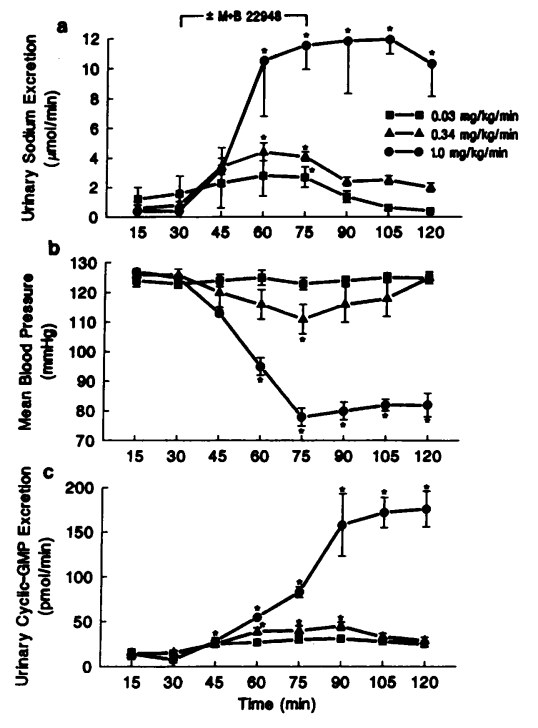

In separate experiments, the following dose regimens were studied: (a) $\mathrm{M}+\mathrm{B} 229480.03 \mathrm{mg} / \mathrm{kg}$ per min for $60 \mathrm{~min}$; AP (103-126) 100 $\mathrm{ng} / \mathrm{kg}$ per $\mathrm{min}$ for $45 \mathrm{~min}$; and the combination ( $n=5$ each group). (b) $\mathrm{M}+\mathrm{B} 229480.34 \mathrm{mg} / \mathrm{kg}$ per min for $60 \mathrm{~min}$; AP (103-126) $100 \mathrm{ng} / \mathrm{kg}$ per min for $45 \mathrm{~min}$; and the combination ( $n=5$ each group). (c) $M$ + B22948 $0.34 \mathrm{mg} / \mathrm{kg}$ per min for $45 \mathrm{~min}$; AP (103-126) $600 \mathrm{ng} / \mathrm{kg}$ per $\min$ for $30 \mathrm{~min}$; and the combination ( $n=6$ each group).

Acute volume expansion. Rats were prepared as described above with the exception that catheters (PE50) were placed in both femoral veins, the additional catheters providing access for volume expansion. As before, the animals were allowed a 90 -min period to regain consciousness in restraining cages before beginning observations and received a maintenance infusion of $5 \%$ dextrose, $0.9 \%$ saline $(0.07 \mathrm{ml} / \mathrm{kg}$ per min), for the duration of the study. After two 15-minute basal urine collections, the rats were divided into two groups: one group $(n=6)$ commenced a $60-\mathrm{min}$ infusion of $\mathrm{M}+\mathrm{B} 229480.1 \mathrm{mg} / \mathrm{kg}$ per $\min$ in $5 \%$ dextrose $(0.9 \%$ saline vehicle), whereas the other group $(n=6)$ continued to receive the vehicle alone. After a third urine collection ( $15 \mathrm{~min}$ ), both groups were volume expanded ( $1 \%$ body wt) with $0.9 \%$ saline (4\% BSA) given over $15 \mathrm{~min}$. Blood samples $(300 \mu \mathrm{l})$ were taken before and after volume expansion for hematocrit and AP immunoreactivity $\left(\mathrm{AP}_{\mathrm{ir}}\right)$ estimations. Urine collections were continued for 60 min after expansion. Blood pressure was noted at the end of each collection period.

Preparation of monoclonal antibody. This was performed using standard methods $(21,22)$. In brief, AP (103-126) was conjugated to bovine thyroglobulin (Sigma Chemical Co., St. Louis, MO) using the carbodiimide-coupling procedure (21). Adult female BALB/c mice were immunized by intraperitoneal injection with $50 \mu \mathrm{g}$ conjugated antigen emulsified in complete Freund's adjuvant, and boosted at 3 -wk intervals with $50 \mu \mathrm{g}$ in incomplete Freund's adjuvant. One mouse with an elevated titer against AP was boosted with $50 \mu \mathrm{g}$ conjugated AP intravenously $4 \mathrm{~d}$ before harvesting spleen cells for fusion.

Spleen cells were fused with mouse myeloma cell line X63-Ag8.653 in the presence of polyethylene glycol 4000 (22). After fusion, the cells were distributed into microtiter plates and cultured in hypoxanthineamphotericin-thymidine medium containing $15 \%$ fetal calf serum. From all wells exhibiting cell growth, supernatants were screened for anti-AP antibodies by radioimmunoassay. Cells from the well that gave the higher titer were cloned twice by the limiting dilution technique in the presence of a mouse thymocyte feeder layer. Positive clones were expanded in cultures and injected intraperitoneally into male BALB/c mice to produce ascitic fluid with highly concentrated antibody.
Antibody was purified from batches of ascitic fluid $(\sim 25 \mathrm{ml})$ by ammonium sulphate precipitation and ion-exchange chromatography. After precipitation, the antibody was dissolved in $0.1 \mathrm{M}$ phosphatebuffered saline ( $\mathrm{pH} 7.5$ ), dialyzed against $10 \mathrm{mM}$ Tris buffer $\mathrm{pH} 8.0$, and passed through a $1.0 \times 13-\mathrm{cm}$ Q-Sepharose (Pharmacia, Uppsala, Sweden) column. The antibody was eluted with a linear gradient of 0-300 mM sodium chloride and the first sharp peak was saved. The antibody was dialyzed against 150 -mM sodium chloride, concentrated by centrifugation in centriprep tubes, mol wt cutoff 10,000 (Amicon Corp., Danvers, MA) and stored $\left(-20^{\circ} \mathrm{C}\right)$ in aliquots of $10 \mathrm{mg} / \mathrm{ml}$ (titer $1: 800,000)$.

Experiments using monoclonal antibody. In radioimmunoassay, the monoclonal antibody raised against rat AP (103-126) showed $100 \%$ cross-reactivity with human AP (99-126) but did not detect porcine brain natriuretic peptide (BNP) (final concentration $1 \mu \mathrm{g}$ per tube). To examine its AP blocking activity in vivo, rats received either monoclonal antibody or an equivalent dose of bovine IgG (Sigma Chemical Co.) in $1 \mathrm{ml} 0.9 \%$ saline. $7.5 \mathrm{mg}$ of AP monoclonal antibody (but not bovine IgG), administered intravenously over $15 \mathrm{~min}$, produced a rise in mean blood pressure $(11 \pm 3 \mathrm{mmHg})$ which fell gradually over the next 2-3 h. This dose of monoclonal antibody completely inhibited the blood pressure and renal response to a 15-min infusion of AP (103-126) $600 \mathrm{ng} / \mathrm{kg}$ per min, a dose that raises plasma $\mathrm{AP}_{\mathrm{ir}}$ levels above $600 \mathrm{pg} / \mathrm{ml}$. However, this dose did not affect the activity of an equivalent dose of porcine brain natriuretic peptide (group $1(n=3)$, Table I) or furosemide $0.5 \mathrm{mg} / \mathrm{kg}$ over $15 \mathrm{~min}$ (group $2(n=3)$ Table I). Thus, the antibody appeared to be specific for the effects of AP.

The effect of monoclonal antibody on volume expansion with and without $\mathrm{M}+\mathrm{B} 22498$ was studied. Rats were prepared as described above and received either monoclonal antibody $(7.5 \mathrm{mg})$ or bovine $\operatorname{lgG}$ in $1 \mathrm{ml}$ of $0.9 \%$ saline $60 \mathrm{~min}$ before the start of observations. The protocols for volume expansion and administration of M + B22948 described above were followed.

Assays. Urine volume was measured gravimetrically and sodium concentration by flame photometer (IL 943; Instrumentation Laboratory, Inc., Lexington, MA). Plasma $\mathrm{AP}_{\mathrm{ir}}$ was measured by an ELISA developed in our laboratory (23). Cyclic GMP concentration was measured by radioimmunoassay. The primary antibody was raised in a

Table I. Effect of Anti-AP MAb on Response to AP (600 ng/kg per min), Porcine BNP (600 ng/kg per min), and Furosemide $(0.5 \mathrm{mg} / \mathrm{kg})$

\begin{tabular}{|c|c|c|c|c|c|}
\hline & & \multirow[b]{2}{*}{ Basal } & \multicolumn{3}{|c|}{$15 \mathrm{~min}$ infusion } \\
\hline & & & pBNP & AP & Furosemide \\
\hline \multicolumn{6}{|l|}{ Group 1} \\
\hline \multirow[t]{3}{*}{ Control } & $\mathrm{U}_{\mathrm{Na}} \mathrm{V}$ & $1.9 \pm 0.4$ & $7.0 \pm 2.4$ & $11.4 \pm 2.3$ & - \\
\hline & BP & $122 \pm 3$ & $115 \pm 2$ & $107 \pm 5$ & - \\
\hline & $\mathrm{U}_{\mathrm{CGMP}} \mathrm{V}$ & $39 \pm 10$ & $168 \pm 32$ & $672 \pm 50$ & - \\
\hline \multirow[t]{3}{*}{ MAb } & $\mathrm{U}_{\mathrm{Na}} \mathrm{V}$ & $1.8 \pm 0.2$ & $5.6 \pm 0.3$ & $2.15 \pm 0.4$ & - \\
\hline & BP & $130 \pm 2$ & $126 \pm 3$ & $129 \pm 3$ & - \\
\hline & $\mathrm{U}_{\mathrm{CGMP}} \mathrm{V}$ & $27 \pm 6$ & $150 \pm 48$ & $60 \pm 12$ & - \\
\hline \multicolumn{6}{|l|}{ Group 2} \\
\hline \multirow[t]{3}{*}{ Control } & $\mathrm{U}_{\mathrm{Na}} \mathrm{V}$ & $2.5 \pm 1.0$ & - & $9.3 \pm 2.2$ & $17.8 \pm 3.2$ \\
\hline & BP & $125 \pm 4$ & - & $111 \pm 4$ & $122 \pm 3$ \\
\hline & $\mathrm{U}_{\mathrm{CGMP}} \mathrm{V}$ & $16 \pm 6$ & - & $500 \pm 64$ & $90 \pm 28$ \\
\hline \multirow[t]{3}{*}{ MAb } & $\mathrm{U}_{\mathrm{Na}} \mathrm{V}$ & $1.0 \pm 0.4$ & - & $1.1 \pm 0.5$ & $14.7 \pm 4.2$ \\
\hline & BP & $134 \pm 3$ & - & $133 \pm 3$ & $128 \pm 4$ \\
\hline & $\mathrm{U}_{\mathrm{CGMP}} \mathrm{V}$ & $22 \pm 5$ & - & $28 \pm 8$ & $40 \pm 17$ \\
\hline
\end{tabular}

Sodium excretion $\left(\mathrm{U}_{\mathrm{Na}} \mathrm{V} ; \mu \mathrm{mol} / \mathrm{min}\right)$, blood pressure (BP; $\mathrm{mmHg}$ ), and urinary cyclic GMP excretion $\left(\mathrm{U}_{\mathrm{cGMP}} \mathrm{V} ; \mathrm{pmol} / \mathrm{min}\right)$. Mean $\pm \operatorname{SEM}(n=3$ each group). 
rabbit against cyclic GMP (Sigma Chemical Co.) conjugated to thyroglobulin (21). $\mathrm{O}^{2}$-monosuccinyl cyclic GMP tyrosine methyl ester (Sigma Chemical Co.) was iodinated by chloramine T method (24), and used as the radioligand. $5 \mu$ lof urine (or appropriate dilution; $1: 1$, 1:10, or 1:50) was incubated overnight in $300 \mu$ l sodium acetate buffer (pH 5.9) with primary antibody (final titer $1: 75,000$ ), goat antirabbit antibody (final titer 1:12,500) and radioligand $(10,000 \mathrm{cpm})$. The following day, each tube received $2 \mathrm{ml}$ distilled water $\left(4^{\circ} \mathrm{C}\right)$ and was centrifuged at 3,000 rpm for $30 \mathrm{~min}$. The supernatant was discarded and the pellet counted by automatic gamma counter. The limit of detection of the assay was $0.25 \mathrm{pmol} /$ tube with intra- and interassay variations of 6 and 14\%, respectively. There was no cross-reactivity of the primary antibody with cyclic AMP.

Statistics. Data are presented as mean \pm SEM. Changes in plasma $\mathrm{AP}_{\mathrm{ir}}$ and hematocrit were analyzed using $t$ test (paired). Changes in mean blood pressure and urinary sodium and cyclic-GMP excretion were analyzed using two-way analysis with overall significance judged by $F$ tests. An orthogonal contrast was conducted to examine the hypothesis that the sum of the effects of the individual treatments (AP and. $M+B 22948$ ) were equal to the effect of the combined treatment.

\section{Results}

$A P(103-126) / M+B 22948$ infusions. An infusion of AP (103-126) $100 \mathrm{ng} / \mathrm{kg}$ per min represents a near threshold dose of the peptide in hydrated conscious rats (hematocrit 45-50\%). Given alone AP (103-126) $100 \mathrm{ng} / \mathrm{kg}$ per min and $\mathrm{M}$ + B22948 $0.03 \mathrm{mg} / \mathrm{kg}$ per min produced modest peak rises in urinary sodium excretion, from 0.43 to 2.41 and 0.97 to 2.62 $\mu \mathrm{mol} / \mathrm{min}$, respectively (Fig. $2 \mathrm{a}$ ). Coadministration of these compounds led to a peak response of $8.9 \mu \mathrm{mol} / \mathrm{min}$, which was significantly greater $(P<0.01)$ than the summation of their individual effects. This synergistic effect on sodium excretion was also seen when the dose of M + B22948 was increased to $0.34 \mathrm{mg} / \mathrm{kg}$ per min; given together, AP (103-126) and M

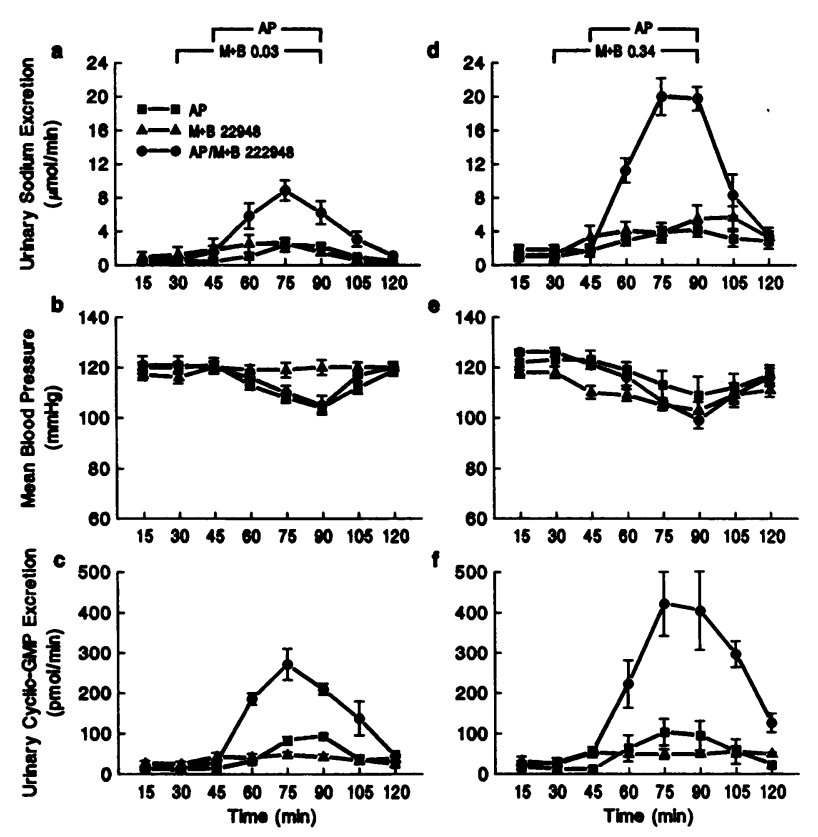

Figure 2. Effect of administration of AP (103-126) $100 \mathrm{ng} / \mathrm{kg}$ per min alone ( $\bullet$ ), and in combination (•) with two doses of $M$ + B22948 (४), $(0.03 \mathrm{mg} / \mathrm{kg}$ per $\mathrm{min}, a-c$; or $0.34 \mathrm{mg} / \mathrm{kg}$ per min, $d-f$ ), on sodium excretion, mean blood pressure, and urinary cyclicGMP excretion. Mean \pm SEM. For significance values see text.
+ B22948 produced a peak response of $20 \mu \mathrm{mol} / \mathrm{min}$, compared with individual responses of 3.7 and $5.5 \mu \mathrm{mol} / \mathrm{min}$, respectively (Fig. $2 d$ ). As expected, AP (103-126) $600 \mathrm{ng} / \mathrm{kg}$ per min, given alone, gave a greater natriuresis than $100 \mathrm{ng} / \mathrm{kg}$ per min (Table II); however, in combination with $M+B 22948$ $0.34 \mathrm{mg} / \mathrm{kg}$ per $\mathrm{min}$, the enhanced natriuresis was comparable to the combined effect of low-dose peptide and $0.34 \mathrm{mg} / \mathrm{kg}$ per min phosphodiesterase inhibitor.

The potentiated natriuretic response to AP (103-126) was accompanied by a synergistic effect on urinary cyclic-GMP excretion (Fig. 2, $c$ and $f$ ). For example, given together, AP $(103-126) 100 \mathrm{ng} / \mathrm{kg}$ per min and M + B22948 $0.34 \mathrm{mg} / \mathrm{kg}$ per min increased urinary cyclic-GMP levels to $422 \mathrm{pmol} / \mathrm{min}$, compared with 103 and $49 \mathrm{pmol} / \mathrm{min}$, respectively, when given alone (Fig. $2 f$ ). Equally important is that although blood sampling was infrequent, there was no evidence that $M$ + B22948 affected the plasma AP $_{\text {ir }}$ levels achieved during the AP (103-126) infusions (Table III).

In contrast to the renal responses are the combined effects of the two compounds on blood pressure. AP (103-126) 100 $\mathrm{ng} / \mathrm{kg}$ per min produced a gradual fall in mean blood pressure (Fig. 2, $b$ and $e$ ). The low dose of M + B22948 had no effect on blood pressure and when given with AP (103-126), no additional fall in pressure was seen (Fig. $2 b$ ). The higher dose of $M$ + B22948 produced a comparable fall in blood pressure (118-103 $\mathrm{mmHg}$ ) to AP (103-126) (122-109 $\mathrm{mmHg})$, but in combination, the peak fall in blood pressure $(126-99 \mathrm{mmHg}$ ) was additive. Thus there was no evidence of potentiation of AP-induced hypotension from these experiments.

Acute volume-expansion experiments. Volume expansion ( $1 \%$ body $\mathrm{wt}$ ) produced a peak natriuresis in the control group of $6.62 \mu \mathrm{mol} / \mathrm{min}$ in the first $15 \mathrm{~min}$ collection after the volume load (Fig. $3 a$ ). This was associated with significant $(P$ $<0.01$ ) rises in plasma $\mathrm{AP}_{\mathrm{ir}}$ (Table IV) and urinary cyclic GMP excretion (Fig. 3 c).

$\mathrm{M}+\mathrm{B} 22948(0.1 \mathrm{mg} / \mathrm{kg}$ per $\mathrm{min})$ alone produced a significant rise $(P<0.05)$ in sodium excretion in the first $15 \mathrm{~min}$ of administration and markedly enhanced natriuresis during and immediately after the volume load. A peak response of 20 $\mu \mathrm{mol} / \mathrm{min}$ was recorded (Fig. $3 a$ ). The rise in plasma $\mathrm{AP}_{\mathrm{ir}}$ and fall in hematocrit were similar to the control group (Table IV), but urinary cyclic-GMP excretion $(155 \pm 31 \mathrm{pmol} / \mathrm{min})$ was significantly $(P<0.01)$ greater than that seen in the control group $(76 \pm 23 \mathrm{pmol} / \mathrm{min})$.

Table II. Natriuretic and BP Response to High-Dose AP (600 $\mathrm{ng} / \mathrm{kg}$ per min) Alone and in Combination with $M+B 22948$ (0.34 $\mathrm{mg} / \mathrm{kg}$ per min)

\begin{tabular}{lcc}
\hline & Basal & Peak response \\
\hline $\mathrm{U}_{\mathrm{Na}} \mathrm{V}(\mu \mathrm{mol} / \mathrm{min})$ & & \\
$\mathrm{AP}$ & $1.2 \pm 0.2$ & $7.7 \pm 0.7$ \\
$\mathrm{M}+\mathrm{B} 22948$ & $1.0 \pm 0.4$ & $6.0 \pm 1.4$ \\
Combination & $0.9 \pm 0.4$ & $17.3 \pm 0.9$ \\
$\mathrm{BP}(\mathrm{mmHg})$ & & \\
$\mathrm{AP}$ & $125 \pm 3$ & $103 \pm 4$ \\
$\mathrm{M}+\mathrm{B} 22948$ & $126 \pm 5$ & $111 \pm 5$ \\
Combination & $122 \pm 4$ & $96 \pm 5$ \\
\hline
\end{tabular}

Mean $\pm \operatorname{SEM}(n=6$ each group). 
Table III. Plasma AP ir $(\mathrm{pg} / \mathrm{ml})$ before and after Infusion of $A P(103-126) 100 \mathrm{ng} / \mathrm{kg}$ per min for 45 min Alone and in Combination with Two Doses of M+B22948.

\begin{tabular}{lrc}
\hline & \multicolumn{2}{c}{$\begin{array}{c}\text { Plasma AP } \\
\text { after AP (103-126) infusion }\end{array}$} \\
\cline { 2 - 3 } & \multicolumn{1}{c}{ Before } & End of infusion \\
\hline & \multicolumn{2}{c}{$p g / \mathrm{ml}$} \\
AP $(103-126)$ alone $(n=10)$ & $91 \pm 11$ & $293 \pm 76^{*}$ \\
Combined with M+B22948 & & \\
$0.03 \mathrm{mg} / \mathrm{kg}$ per $\min (n=5)$ & $53 \pm 30$ & $370 \pm 102^{*}$ \\
$0.34 \mathrm{mg} / \mathrm{kg}$ per $\min (n=5)$ & $114 \pm 36$ & $365 \pm 40^{*}$ \\
\hline
\end{tabular}

Mean \pm SEM. ${ }^{*}, P<0.01$ (compared with baseline).

Pretreatment with monoclonal antibody against AP led to significant inhibition of the natriuretic response to volume expansion when compared with the control group $(P<0.05$; time 60-90) and attenuated the response seen in the $M$ + B22948-treated rats $(P<0.01 ; M+B 22948 \pm$ antibody, time 60-90) (Fig. $3 a$ ). The pattern of natriuresis was also changed from that of a rapid response followed by a decline to one of a gradual increase in sodium excretion after volume loading. The antibody had no significant effect on basal urinary cyclicGMP levels but completely blocked the rapid rise in levels associated with volume expansion in both control- and $\mathbf{M}$ + B22948-treated groups (Fig. $3 c$ ).

\section{Discussion}

Although it has been recognized for some time that cyclic GMP is an intracellular mediator of the vasorelaxant actions of endothelium-derived relaxant factor and the nitrous-containing vasodilators (13), the idea that this nucleotide is involved in the renal regulation of sodium excretion has only recently received support. Following the lead given by AP,
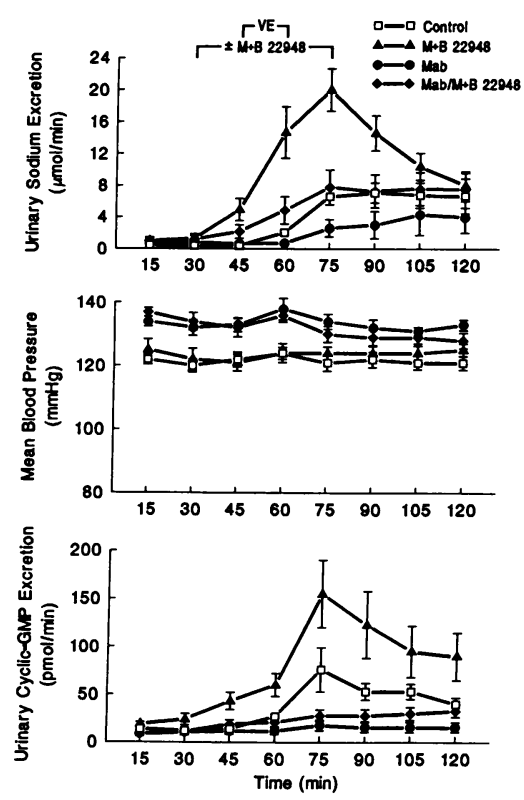

Figure 3. Comparison of effect of volume expansion ( $1 \%$ body wt, period $45-60 \mathrm{~min}$ ) on (a) sodium excretion; (b) mean blood pressure; and $(c)$ urinary cyclic-GMP excretion in control ( $\square$ ), $M$ + B22948 (•), anti-AP $\mathrm{MAb}(\bullet)$, and $\mathrm{Mab} / \mathrm{M}$ + B22948- ( $\bullet)$ treated rats. The dose of $\mathrm{M}$ + B22948 used was 0.1 $\mathrm{mg} / \mathrm{kg}$ per min. Data presented are mean \pm SEM. For significance values see text.
Table IV. Effect of Acute Volume Expansion on $A P_{i r}(\mathrm{pg} / \mathrm{ml})$ and Hematocrit (\%) in Control, $M+B 22948, M A b$, and $M A b / M+B 22948-$ treated Rats

\begin{tabular}{llcc}
\hline & & \multicolumn{2}{c}{ Volume expansion } \\
\cline { 3 - 4 } & & Before & After \\
\hline \multirow{4}{*}{$\mathrm{AP}_{\text {ir }}(p g / m l)$} & Control & \multicolumn{2}{c}{$1 \%$ body $w t$} \\
& M+B22948 & $54 \pm 10$ & $353 \pm 85^{*}$ \\
& AP MAb & $85 \pm 10$ & $273 \pm 42^{*}$ \\
& AP MAb+M+B22948 & - & - \\
Hematocrit (\%) & Control & $48 \pm 0.6$ & $42 \pm 0.8^{*}$ \\
& M+B22948 & $48 \pm 0.9$ & $42 \pm 0.9^{*}$ \\
& MAb & $49 \pm 0.4$ & $40 \pm 0.9^{*}$ \\
& MAb+M+B22948 & $47 \pm 1.4$ & $39 \pm 0.5^{*}$ \\
& & & \\
& & &
\end{tabular}

Mean \pm SEM. ${ }^{*}, P<0.01$ (compared with baseline).

analogues of cyclic GMP have been shown to increase intraglomerular hydrostatic pressure (6) and inhibit sodium transport across inner medullary collecting ducts $(14,15)$. $\mathrm{M}$ + B22948 exhibits selectivity for a cyclic GMP-specific low $\mathrm{K}_{\mathrm{m}}$ phosphodiesterase over the corresponding cyclic AMPspecific enzyme (20). The observation that in vivo administration of this drug increases urinary sodium as well as urinary cyclic-GMP levels is consistent with the hypothesis that cyclic GMP contributes to the regulation of urinary sodium excretion.

A characteristic of cyclic nucleotide-mediated responses to peptide hormones is enhanced effects of submaximal hormone doses in the presence of phosphodiesterase inhibition (25). Coadministration of low doses of AP and M + B22948 greatly potentiated the rise in urinary sodium excretion seen with either compound alone. The enhanced natriuresis occurred in the absence of an effect of $\mathrm{M}+\mathrm{B} 22948$ on plasma $\mathrm{AP}_{\mathrm{ir}}$ concentration achieved during infusion of the peptide and was accompanied by potentiation of the rise in urinary cyclicGMP excretion. It cannot be assumed that the marked rise in urinary cyclic-GMP levels observed in this study were entirely nephrogenous in origin. Nonetheless, it provides evidence that M + B22948 is capable of potentiating the cyclic-GMP response to AP and this seems to be the most likely mechanism by which the drug facilitated the renal response to the peptide. These findings argue that cyclic GMP is a mediator of the natriuretic activity of AP. It is interesting that infusing a higher dose of AP (600 $\mathrm{ng} / \mathrm{kg}$ per min) with the phosphodiesterase inhibitor produced no further gain in sodium excretion over the low-dose AP-M + B22948 combination. This may reflect the somewhat greater fall in blood pressure observed in the high-dose AP-M + B22948 group. Alternatively, it may indicate saturation of the cyclic GMP-mediated natriuretic pathway.

An important observation is that cyclic-GMP phosphodiesterase inhibition enhanced the natriuretic properties of AP without inducing detrimental falls in blood pressure. In particular, the combination of low-dose M + B22948 (which itself did not affect blood pressure) with low-dose AP led to a rise in sodium excretion of similar magnitude to that produced by high-dose AP alone, but was accompanied by a smaller reduc- 
tion in blood pressure. Although $\mathrm{M}+\mathrm{B} 22948$ has been reported to enhance AP-induced vasorelaxation in vitro (26), it is important to note that vasodilation is probably a small contributor to AP-induced hypotension in vivo. A more important factor is thought to be a reduction in cardiac output (27) and the physiological and biochemical mechanisms underlying this action of AP are unclear. Recently, Met- $\mathrm{O}^{110}$-AP, an analogue of AP which does not increase cyclic GMP in vascular smooth muscle, has been reported to be equipotent with AP in reducing blood pressure in rats (28). These data and our own cast some doubt on the role of cyclic GMP as a mediator of the blood pressure, lowering effects of AP.

Several authors have reported an increase in plasma $\mathrm{AP}_{\mathrm{ir}}$ and urinary cyclic-GMP levels after volume expansion and suggested that these changes may contribute to the ensuing natriuresis $(3,29)$. We used $M+B 22948$ and a monoclonal antibody directed against AP to examine the relationship between AP, cyclic GMP, and sodium excretion in this condition. Volume loading by $1 \%$ body wt produced rises in plasma $\mathrm{AP}_{\mathrm{ir}}$ and urinary cyclic-GMP excretion of similar magnitude to those observed with the low-dose infusion of AP (103-126). Pretreatment with anti-AP monoclonal antibody produced a transient rise in blood pressure that was not reproduced by bovine IgG. Similarly, in related studies, we have found that equivalent doses of a monoclonal antibody directed against porcine BNP does not alter blood pressure. This suggests that the effect of the anti-AP monoclonal antibody on blood pressure was related to inhibition of circulating AP, as suggested by other authors $(30,31)$. The anti-AP monoclonal antibody did not reduce basal sodium excretion but blunted the natriuretic response to volume expansion and completely inhibited the rise in urinary cyclic-GMP excretion. These findings are consistent with those of Hirth and colleagues $(5,30)$ and indicate that AP is an important contributor to the natriuresis of acute volume expansion and a major determinant of the rise in urinary cyclic GMP associated with this stimulus. M + B22948 produced striking potentiation of the natriuresis observed during and after volume loading, an effect that was markedly attenuated by the anti-AP monoclonal antibody. It is not surprising that the effect of $\mathrm{M}+\mathrm{B} 22948$ was not completely blocked; in the short period between administration of the antibody and drug, the antibody had little effect on basal urinary cyclic-GMP excretion, suggesting renal tissue cyclicGMP levels were not depleted. However, it is clear that $\mathbf{M}$ + B22948 was dependent on the AP-driven surge in cyclicGMP levels associated with volume loading for its striking effects on sodium excretion. Thus, cyclic GMP appears to play an active role in mediating the AP-stimulated natriuresis associated with acute volume expansion.

Our findings may have a therapeutic application. The discovery of AP raised the possibility of a new therapeutic agent for the management of disorders of sodium and water balance. Unfortunately, a serious limitation of the efficacy of exogenous AP infusions is that, at high doses of the peptide, the natriuretic response is attenuated by the accompanying fall in blood pressure and renal perfusion pressure. We have shown that postreceptor potentiation of the cyclic-GMP response to AP using a cyclic-GMP phosphodiesterase inhibitor enhances the renal response to AP without detrimental falls in blood pressure. Coadministration of low doses of AP with a cyclicGMP phosphodiesterase inhibitor or administration of the inhibitor alone (when plasma AP levels are already significantly elevated) may offer a novel strategy for the management of disorders associated with sodium and water retention.

\section{Acknowledgments}

We are grateful to Dr. David Reitz of G. D. Searle \& Co., Chicago, IL, for the synthesis and supply of M + B22948 used in these studies.

\section{References}

1. Needleman, P., and J. E. Greenwald. 1986. Atriopeptin: a cardiac hormone intimately involved in fluid, electrolyte and blood pressure homeostasis. N. Engl. J. Med. 314:828-834.

2. Dietz, J. R. 1984. Release of atrial natriuretic factor from a rat heart-lung preparation by atrial distension. Am. J. Physiol. 247:R1093-R1096.

3. Lewis, H. M., M. R. Wilkins, B. M. Selwyn, V. J. Yellard, M. E. Griffith, and K. D. Bhoola. 1988. Urinary guanosine $3^{\prime}: 5^{\prime}$-cyclic monophosphate but not tissue kallikrein follows the plasma atrial natriuretic factor response to acute volume expansion with saline. Clin. Sci. (Lond.). 75:489-494.

4. Wilkins, M. R., J. A. Wood, D. Adv, C. J. Lote, M. J. Kendall, and $\mathrm{J}$. Michael. 1986. Change in plasma immunoreactive atrial natriuretic peptide during sequential ultrafiltration and hemodialysis. Clin. Sci. (Lond.). 71:157-160.

5. Hirth, C., J-P. Smith, A. John, S. Kazda, F. Morich, D. Neuser, and $\mathrm{S}$. Wohlfeil. 1986. The renal response to acute hypervolemia is caused by atrial natriuretic peptides. J. Cardiovasc. Pharmacol. $8: 268-275$.

6. Huang, C-L., H. E. Ives, and M. G. Cogan. 1986. In vivo evidence that cGMP is the second messenger for atrial natriuretic factor. Proc. Natl. Acad. Sci. USA. 83:8015-8018.

7. Tremlay, J., R. Gertzer, P. Vinay, S. C. Parg, R. Beliveau, and P. Hamet 1985. The increase of cGMP by atrial natriuretic factor correlates with the distribution of particulate guanylate cyclase. FEBS (Fed. Eur. Biochem. Soc.) Lett. 181:17-22.

8. Martin, W., D. G. White, and A. H. Henderson. 1988. Endothelium-derived relaxing factor and atriopeptin II elevate cyclic GMP levels in pig aortic endothelial cells. Br. J. Pharmacol. 93:229-239.

9. Waldman, S. A., R. M. Rapoport, and F. Murad. 1984. Atrial natriuretic factor selectively activates particulate guanylate cyclase and elevates cyclic GMP in rat tissues. J. Biol. Chem. 259:14332-14334.

10. Winquist, R. J., E. P. Faisòn, S. A. Waldman, K. Schwartz, F. Murad, and R. M. Rapoport. 1984. Atrial natriuretic factor elicits an endothelium-independent relaxation and activates particulate guanylate cyclase in vascular smooth muscle. Proc. Natl. Acad. Sci. USA. 81:7661-7664.

11. Matsuoka, H., M. Ishii, T. Sugimoto, Y. Hirata, T. Sugmoto, K. Kangawa, and H. Matsuo. 1985. Inhibition of aldosterone production by $\alpha$ human atrial natriuretic polypeptide is associated with an increase in cGMP production. Biochem. Biophys. Res. Commun. 127:1052-1056.

12. Chinkers, M., D. L. Garbers, M. S. Chang, D. G. Lowe, H. Chin, D. V. Goeddel, and S. Schulz. 1989. A membrane form of guanylate cyclase is an atrial natriuretic peptide receptor. Nature (Lond.). 338:78-83.

13. Waldman, S. A., and F. Murad. 1987. Cyclic GMP synthesis and function. Pharmacol. Rev. 39:163-296.

14. Zeidel, M. L., P. Silva, B. M. Brenner, and J. L. Seifter. 1987. cGMP mediates effects of atrial peptides on medullary collecting duct cells. Am. J. Physiol. 252:F551-F-559.

15. Light, D. B., E. B. Schwiebert, K. H. Karlson, and B. A. Stanton. 1989. Atrial natriuretic peptide inhibits a cation channel in renal inner medullary collecting duct cells. Science (Wash. DC). 243:383385 .

16. Henrich, W. L., E. A. McAllister, P. B. Smith, and W. B. Campbell. 1988. Guanosine 3':5'-cyclic monophosphate as a mediator of inhibition of renin release. Am. J. Physiol. 255:F474-F478.

17. Wong, K. R., M.-H. Xie, L.-B. Shi, F.-Y. Liu, C.-L. Huang, 
D. G. Gardener, and M. G. Cogan. 1988. Urinary cGMP as biologica marker of the renal activity of atrial natriuretic factor. Am. J. Physiol. 255:F1220-F1224.

18. Seymour, A. A., E. H. Blaine, E. K. Mazack, S. G. Smith, I. I. Stabilito, A. B. Haley, M. A. Napier, M. A. Whinnery, and R. F. Nutt. 1985. Renal and systemic effects of synthetic atrial natriuretic factor. Life Sci. 36:33-44.

19. Ito, K., T. Yukimura, T. Takenaga, K. Yamamoto, K. Kangawa, and H. Matsuo. 1988. Small intestine as possible source of increase plasma cGMP after administration of $\alpha$-hANP to dogs. $A m$.J. Physiol. G814-G818.

20. Bergstrand, H., J. Kristofferson, B. Lundquist, and A. Schurmann. 1976. Effects of antiallergic agents, compound $48 / 80$ and some reference inhibitors on the activity of partially purified human lung tissue adenosine cyclic 3':5'-monophosphate and guanosine cyclic 3':5'-monophosphate phosphodiesterase. Mol. Pharmacol. 13:38-43.

21. Baumingers, S., and M. Wilchek. 1980. The use of carbodiimides in the preparation of immunizing conjugates. Methods Enzymol. 70:151-159.

22. Galfre, G., S. C. Howe, C. Milstein, G. W. Butches, and J. C. Howard. 1977. Antibodies to major histocompatibility antigens produced by hybrid cell lines. Nature (Lond.). 266:550-552.

23. McLaughlin, L. L., W. Yuefang, P. T. Stockman, K. Leahy, P. Needleman, J. Grassi, and P. Pradelles. 1987. Development, validation, and application of an enzyme immunoassay (EIA) of atriopeptin. Biochem. Biophys. Res. Commun. 144:469-476.

24. Greenwood, F. C., W. M. Hunter, and J. S. Glover. 1983. The preparation of ${ }^{131} \mathrm{I}$-labelled human growth hormone of high specific radioactivity. Biochem. J. 89:114-123.

25. Sutherland, E. W. 1972. Studies on the mechanism of hormone action. Science (Wash. DC). 177:401-408.

26. Martin, W., R. O. Morgan, J. A. Smith, and D. G. White. 1986. Atriopeptin II-induced relaxation of rabbit aorta is potentiated by $\mathbf{M}$ + B22948 but not blocked by haemoglobin. Br. J. Pharmacol. 89:557-561.

27. Trippodo, N. C., and R. W. Barbee. 1987. Atrial natriuretic factor decreases whole-body capillary absorption in rats. Am. J. Physiol. 252:R915-R920.

28. Willeubrock, R. C., J. Tremblay, R. Garcia, and P. Hamet. 1989. Dissociation of natriuresis and diuresis and heterogeneity of the effector system of atrial natriuretic factor in rats. J. Clin. Invest. 83:482-489.

29. Gerbes, A. L., R. M. Arendt, R. Gerzer, W. Schnizer, D. Jungst, G. Paumgartner, and H. Wernze. 1988. Role of atrial natriuretic factor, cyclic GMP and the renin-aldosterone system in acute volume regulation of healthy human subjects. Eur. J. Clin. Invest. 18:425-429.

30. Stasch, J.-P., C. Hirth, S. Kazda, and S. Wohlfeil. 1986. The elevation of cyclic GMP as a response to acute hypervolemia is blocked by monoclonal antibody directed against atrial natriuretic peptides. Eur. J. Pharmacol. 129:165-168.

31. Sasak, A., O. Kida, J. Kato, S. Nakamura, K. Kodama, A. Miyata, K. Kargawa, H. Matsuo, and K. Tanaka. 1987. Effects of antiserum against $\alpha$-rat atrial natriuretic peptide in anesthetized rats. Hypertension (Dallas). 10:308-312. 